\title{
Impacts on Flash Urban Floods of Urbanization, Climate Change and Mismanagement
}

\author{
Ylldırım Bayazıt ${ }^{1}$, Cengiz koç ${ }^{2}$, and Recep Bakış3 \\ ${ }^{1}$ Bilecik Seyh Edebali Universitesi \\ ${ }^{2}$ Muğla Sitkı Koçman Üniversitesi \\ ${ }^{3}$ Eskişehir Technical University
}

May 22, 2020

\begin{abstract}
Floods are among the most dangerous natural disasters that affect the development of a region. Flood events worldwide cause the utmost casualties and property damage. Increasing urbanization and population have significant impacts on the natural environment. Human activities such as uncontrolled building constructions in urban areas, land use changes and lack of urban planning, all affect floods. In urban flood management, determining the size and risk areas of the flood is extremely important in order to reduce the possible losses. In this study, five basins which have been experiencing floods caused by climate change and increasing urbanization in Bodrum, which is one of Turkey's most important tourism centers, have been examined. Maximum flood flow rates were calculated in these basins by using Soil Conservation-Curve Number (SCS-CN) precipitation-flow model with the effect of urbanization changes in 1984, 2010, 2011 and 2019. Flood hydrographs of the basins for the years studied were determined. In addition, Multiple Criteria Decision Making (MCDM) model was used to create flood risk maps of basins. As a result of the study, it was determined that the increase in urbanization in the period from 1984 to 2019, caused the flood flows to increase as well as the areas at risk to increase. The flood problems caused by urban growth and distorted urbanization were identified and measures and suggestions to be taken in urban flood management were introduced.
\end{abstract}

\section{Introduction}

Flood events are becoming less predictable due to the increase in population and urban areas, global warming and climate change. The risk of flooding in urban centers is quite high, and especially the rapid growth of cities located on rivers and coasts, leads to increased flooding of people and buildings (Jha et al., 2012). Global climate change in connection with the increasing world population shows that flood disasters will continue to increase (Hirabayashi et al., 2013; Wahl et al., 2015). It is known that the places where flood losses are seen most effectively are urban areas where urbanization is high. Today, about $55 \%$ of the global population lives in cities. This figure is expected to reach $68 \%$ by 2050 (United Nations, 2018). The number of flood events and the resulting losses are still increasing and constitute $45 \%$ of people affected by disasters occurring between 1998 and 2017 worldwide (UNISAR, 1998-2017). It is reported that in 2018, 683 of 1860 cities, in other words, more than one third of them were located in areas with high flood risk (Gu, 2019). It is known that the cities where flood risk is high are especially coastline cities. Increasing precipitation events and rising sea levels increase the flood risk in these cities (Buurman and Babovic, 2016; Hallegatte al., 2013; Hansen and Pauleit, 2014). Another important factor affecting the flood risk is the change of land use. Especially urbanization causes an increase in impermeable surfaces that prevent falling precipitation from leaking underground (Chen et al., 2013; Jacobson, 2011; Liu et al., 2015; Kuang et al., 2016; Scholz, 2004). Changes in land use, increased urbanization and the effects of climate change increase the complexity between cities and city floods (Pettersson et al., 2018). In many studies, Pathirona et al (2014) investigated the effects of flood hazard and urban growth, land use changes due to urban growth on extreme precipitation 
variability in and around cities with sensitivity studies. Impermeable surfaces increase the flow volume of the falling precipitation significantly and thus increase the flood flow size. In addition, they shorten the time that the flow reaches from the spring to the downstream, causing sudden floods (Abas and Hashim, 2014). Many studies have shown that a flood risk study should be considered as part of the urban planning process (Zhou et al., 2019; Liao, 2012). Rapid increase in urban population, inadequate urban drainage design and aging of infrastructure are exposing people and buildings to flood risk (Miller et al., 2017; Sörensen et al., 2017). Various studies have been conducted to evaluate the effect of changes in land use on the amount of flow. Many researchers have revealed that the increase in urban activities in flood plains increases peak flows, shortens the peak time and increases the flow volume (Sonyel and Lu, 2004; Israel, 2015). Some studies have examined the effect of floods on the built environment (Ahmad et al., 2019). The importance of urban development and changes in precipitation have evaluated the worst possible consequences of flood disaster in a city and show that on average 1.7 times more buildings are exposed to flood hazards each year (Devi et al., 2019). Remote sensing techniques and Geographic Information Systems (GIS) applications are useful tools in determining the relationship between urbanization and river flows. Satellite imagery is an indispensable resource for pre-planning against many natural disasters, determining risk zones and monitoring the results with its wide range and continuous detection capabilities. Since the effect of urbanization on floods is taken into account, the determination of land changes from satellite images reveals that this is an important data source. In the literature, different remote sensing techniques are used to create land use maps from satellite images (Lockaby et al., 2011; O'Driscoll et al., 2010; Walsh et al., 2016; Walega et al., 2020). Determining the size of the flood is another important factor in risk management to minimize flood losses. Methods such as Synder, Kirpich, Mockus and Soil Conservation Service-Curve Number (SCS-CN) are used to determine the flood size (Chikwue, 2019; Salimi et al., 2017; Sudhakar et al., 2015). SCS-CN method, which is known as the method that shows the effect of land change in the best way, was used in this study. A method, Curve Number-CN, was developed in 1972 by the U.S. Soil Conservation Service (SCS) to analyze the relationship between precipitation and flow-loss (USDA, 1972). This method, called SCS-CN, has been tested with flow measurements especially in small-scale basins and the validity of the method has been demonstrated by numerous studies (Walega and Salata, 2019; Ajmal et al., 2015; Shadeed and Almasri, 2010; Xiao et al., 2011; Kousari et al., 2010; Matomela et al., 2019; Satheeshkumar et al., 2017). In addition to knowing the size of the flood in flood risk management, it is very important to identify the risk areas. Multi-criteria decision-making models are among the methods that can be used to identify flood risk areas. These models can provide accurate and stable results, as they can handle each parameter that has an inherent complexity and uncertainty, which is the nature of flood risk management (Yan et al., 2011; Zagonari and Rossi, 2013). Therefore, Multiple Criteria Decision-Making models have been used by the scientific community in flood risk management studies (Hassan et al., 2019; Umar et al., 2019; Paliaga et al., 2019; Mishra and Sinha, 2020; Barthrellos et al., 2016). In a study, the increase in the use of this model in flood risk assessment studies was analyzed (Brito and Evers, 2016). According to the study, it was reported that the use of this method will continue to increase in the coming years. This indicates that the method is a commonly used and accepted method for flood risk management.

In this study, Bodrum, which is a coastal city recognized as a major tourist destination in Turkey and in the world, has been examined. Aliyan, Gerence, Gökçeler, Çukur and Gaz basins, are places where floods occur frequently in Bodrum, as they are locations where population and urbanization are high. In the study, the change of land use from satellite images of 1984, 2010, 2011 and 2019 is discussed. The effect of this change on flood sizes was investigated by the SCS-CN method. In addition, the variation of land use changes in flooded risk areas in the studied basins was demonstrated through the Multi-Criteria Decision-Making model. As a result of the study, it is aimed to reveal the flood magnitudes and risk areas in urban flood management and the measures that need to be taken.

\section{Study Area}

Bodrum peninsula is an important tourist city located in the south-western tip of Turkey (Fig.1). The peninsula is located at $37^{\circ} 2^{\prime} 18^{\prime \prime}$ North latitude, $27^{\circ} 25^{\prime} 45^{\prime \prime}$ East longitude. There is Güllük Gulf on the north of the peninsula and Aegean Sea on the west of Gökova Gulf. Bodrum peninsula has an area of $680 \mathrm{~km}^{2}$ and 
a coastline of $174 \mathrm{~km}$. The region is under the influence of the Mediterranean climate. The peninsula has hot and arid summers as well as mild and rainy winters. Since the Bodrum peninsula is an important tourism region, the population distribution of the region is concentrated on the coastline of the peninsula. Especially with the increasing population on the coastline, urbanization has also increased rapidly. In recent years, flood news that the region is exposed to, are frequently encountered in local and national press. Especially in regions where urbanization is intense, many flood events occur during rainy periods. The streams where the floods occur most frequently are located in the south of the peninsula and are downstream from the sea. Floods are thought to occur frequently as the stream beds (flood drainage system) in these regions lose their natural condition as a result of urbanization. For this reason, in this study, Aliyan, Gerence, Gokceler, Cukur and Gaz streams and basins, where floods occur frequently, were examined.

Fig.1. Location of the Bodrum peninsula in Turkey

\section{Data and Method}

\subsection{Data Collection}

A lot of data was needed to be used in the methods applied in the study. These data and their attainment are given under the following headings.

\subsubsection{Digital Elevation Model}

DEM data with a resolution of $30 \mathrm{~m} \times 30 \mathrm{~m}$ to determine hydrological parameters of the basins studied in the study such as slope, flow direction, sum of flow and synthetic drainage networks were obtained from the United States Geological Survey Global Earth Explorer (USGS) website (U.S. Geological Survey, 2020). The data received is in the form of 2 SRTM 1 Arc-Second Global DEM images, covering the Bodrum peninsula. These data were later cut to the basin boundaries studied and clip studies were carried out.

\subsubsection{Satellite Images}

In the study, satellite images of 1984, 2010, 2011 and 2019 were used to examine the change of land use. Satellite images were taken from two different sources. While satellite images of 2010 and 2011 were provided as Landsat images from USGS, satellite images from 1984 and 2019 were taken from Google Earth satellite images (Google Earth, 2020). Since Landsat satellite images had the satellite image belonging to the region only until 2007, it was thought that this would not allow to examine the land use change. For this reason, Google's data was used for providing satellite images of 1984 and 2019. Satellite images and features used in the study are given in Table 1. In the ArcGIS 10.2 software, which is a Geographical Information Systems (GIS) software, a controlled classification was conducted on satellite images, and subsequently land use maps of the region were obtained.

Table 1. Landsat scenes used in the study

\subsubsection{Soil Parameters}

The Bodrum peninsula soil structure consists of Paleozoic aged schists and limestones in general. Since the parts of the peninsula close to the sea are made of limestone, they tend to be poor in terms of surface water. There are more abundant water resources in the interior. District lands and properties of Turkey's General Directorate of Mineral Research and Exploration geology maps were obtained from the map viewer and editor (MTA, 2020).

\subsubsection{Rainfall Data}

Rainfall data is one of the most important data of flood peak flow and risk analysis. These data can be obtained in the form of daily, monthly and yearly records of the precipitation in the region. These data are kept in records in Turkey by the General Directorate of Meteorology. In this study, the data of 3 precipitation measuring meteorology stations located in the immediate vicinity of the studied basins were obtained from global weather data developed for Soil \& Water Assessment Tool (SWAT) analysis. General information about downloaded precipitation data is given in Table 2 . 
Table 2. Features of precipitation data used in the study

Graphs were created by calculating the monthly maximum heights of the daily precipitation heights in 3 meteorology stations in the region to measure the flood peak flow (Fig.2).

Fig.2. Monthly maximum and average precipitation heights

These data were then utilized as a base for analysis of flood risk mapping, as precipitation distribution maps were created on the basins examined using the Inverse Distance Weighted (IDW) positional interpolation method.

\subsubsection{Population Data}

In order to reveal the relationship between urbanization and population growth in the region, population data for the years 2007-2019 of the Bodrum peninsula, was obtained from Turkey Statistics Institute (TSI) database (TSI, 2019). Annual population growth rate in the region was calculated as $4.94 \%$. A population projection up to 2050 for 5-year intervals in Bodrum peninsula was made by the method of the Turkish Bank of Provinces (Fig.3). The equation used in this method is given below.

$P_{\text {future }}=P_{\text {past }}(1+i)^{N}(1)$

Here $\mathrm{P}_{\text {future }}=$ future population, $\mathrm{P}_{\text {past }}=$ past population, $\mathrm{i}=$ annual population growth rate and $\mathrm{N}=$ projection years

Fig.3. Population projection of the Bodrum peninsula

According to the population projection, the number of people living on the Bodrum peninsula in 2050 is estimated to be 782,142 people. In their study, Koc et al (2017) calculated the population of the basement peninsula in the years 2030, 2040 and 2050 as 577145, 750027 and 922110, respectively. This figure is the number of people residing in the region. Considering the touristic potential of the region, it should be taken into consideration that this figure will be much higher.

\subsection{Method}

Two different methods were used in this study. As the first method, the flood peak flows of Aliyan, Gerence, Gokceler, Cukur and Gaz streams, which frequently experience flooding in the region, were calculated with the SCS method. Flood hydrographs of streams were created taking into account the land use changes of 1984, 2010, 2011 and 2019. In another part of the study, Multiple Criteria Decision Analysis method was used to create flood risk maps of the streams examined on a basin basis.

\subsubsection{The SCS-CN Runoff Model}

The Soil Conservation Service (SCS) method used in hydrological applications, was used to determine the direct current hydrograph created by a precipitation in the basin. The method used in the study is given in Fig.4 as flow chart.

Fig.4. SCS-CN methodology of the study

The SCS-CN method was developed by the United States Department of Agriculture (USDA) to calculate flood flows (USDA, 1972). In this method, the residual precipitation is calculated as per Equation 2.

$P_{e}=(P-0.2 S)^{2} /(P+0.8 S)(2)$

In Equation 2, $\mathrm{P}_{\mathrm{e}}$ now shows residual precipitation $(\mathrm{mm}) . \mathrm{S}$ in Equation 2 depends on soil type and initial humidity and is calculated as given in Equation 3 with CN curve numbers.

$S=\left(\left(\frac{1000}{\mathrm{CN}}\right)-10\right) * 25.4(3)$

The CN number, which passes to Equation 3, is a number determined based on the soil / land cover (LU / LC) that allows leakage of falling rainfall according to the land use and ground moisture condition (Amutha and Porchelvan, 2009). According to the U.S Soil Conservation Service (SCS), soil classes are classified under 
four hydrological soil groups (HSG) as A, B, C and D according to the probable flow and final infiltration rate (Table 3).

Table 3. SCS hydrologic soil groups (U.S Conservation Service, 1972)

The peak flow of the unit hydrograph according to the unit area is determined by calculating the CN numbers determined according to the land use conditions of the basins examined in the study and hydrological soil classes, as calculated and shown in the results and discussions section.

The peak flow of the unit hydrograph per unit area is found with the help of Equation 4.

$q_{p}=0.208 * A / T_{p}(4)$

Here $\mathrm{q}_{\mathrm{p}}$ is the peak flow rate $(\mathrm{m} 3 / \mathrm{s} / \mathrm{mm})$ of the flood unit hydrograph and the parameter $\mathrm{A}$ is the basin area $(\mathrm{km} 2)$.

The total duration of the basin is calculated as $\mathrm{T}_{\mathrm{c}}(\mathrm{min})$ with the equation given in equation

$5 . T_{c}=0.02 *\left(\left(L^{0.77}\right) *(H / L)^{-0.385}\right)(5)$

Here $\mathrm{L}$ gives the length of the stream bed $(\mathrm{m})$, the difference in height between the $\mathrm{H}$ basin entrance and exit. The expression $\mathrm{H} / \mathrm{L}$ here refers to the harmonic slope of the stream bed. After $\mathrm{T}_{\mathrm{c}}$ is found, the calculations are as shown in Equation 6, which shows the hydrograph rise time of the stream in the basin.

$T_{p}=0.7 * T_{c}(6)$

Thus, unit hydrographs of the direct flow that will occur in the basins are determined. Flood hydrographs were created with the help of equation 7, using the unit hydrograph flow values calculated in Equation 4 .

$$
\left.\mathrm{Q}_{\max }=\left(P_{e} * q_{p}\right)+Q_{\mathrm{baz}}\right)(7)
$$

Here, $P_{e}$ expresses effective precipitation $(\mathrm{mm}), \mathrm{q}_{\mathrm{p}}$ unit hydrograph peak flow $\left(\mathrm{m}^{3} / \mathrm{s} / \mathrm{mm}\right)$, and $\mathrm{Q}_{\mathrm{base}}$ is the base flow $\left(\mathrm{m}^{3} / \mathrm{s}\right)$.

\subsubsection{Multi-Criteria Decision Analysis}

The method is the process of evaluating a finite number of options, which are often weighted, contradicting, and not using the same unit of measurement, even some of which take qualitative values, by selecting, sorting, classifying, prioritizing or eliminating them (Yoon and Hwang, 1995). The Analytical Hierarchy Process (AHP) is used in a multi-criteria, multi-purpose decision-making situations with many decision makers when choosing from multiple alternatives under certainty or uncertainty. AHP allows decision makers to model complex problems in a hierarchical structure that shows the relationship between the main goal, criteria, sub-criteria, and alternatives. The most important feature of AHP is that the decision maker can include both objective and subjective thoughts in the decision process. The decision-making process can result in the decision maker choosing, sorting or classifying from the available options. AHP uses a hierarchical model consisting of goals, criteria, possible sub-criteria levels and options for each problem. It is a general method for complex, incomprehensible or unstructured problems and is built on three basic principles:

* Creating Hierarchies

* Determination of Priorities

* Logical and Numerical Consistency

While determining the risky areas in the applied method, the parameters were handled one by one. The basic elements of flood risk realized for the basin are the geographical features of the basin and the flood characteristics. The flow chart of the method is given in Fig.5.

Fig.5. Multi-Criteria Decision Analysis flowchart of the study 
In the applied AHP, the parameters related to the flood risk in the study area were evaluated according to the AHP assessment scale and each of them was given a weight value. This process was applied separately for the 5 basins in the study. Weight values range from 1-9. The closest to 1 has the least risk, the closest to 9 has the most risk (Table 4 ).

Table 4. The importance of weight values in Analytical Hierarchy Process

\section{Result and Discussions}

\subsection{The SCS-CN Runoff Model Results}

In the SCS-CN Rainfall-Flow model, the satellite images of 1984, 2010, 2011 and 2019 were first classified and the average values of CN numbers were calculated according to the land use areas by evaluating the region's soil data. In the controlled classification, land use maps for basins were created under 3 classifications of forest, bare land and residential area. Average CN values of Aliyan, Gerence, Gokceler, Cukur and Gaz Basins examined in the study are provided in Table 5.

Table 5. Land use change and $\mathrm{CN}$ values of the basins examined in the study by years

After calculating the $\mathrm{CN}$ values of the basins according to the years studied, some basin parameters in the SCS equations were calculated by basin analysis in GIS. The parameters of Aliyan, Gerence, Gokceler, Cukur and Gaz Basins are provided in Table 6.

Table 6. Basin Parameters

When the data of three stations measuring the precipitation area in the study area are evaluated on basin basis, $\mathrm{P}$ (precipitation heights) values for each basin are calculated. After calculating the precipitation heights of the basins and the parameters given in Table 6, S (Potential Maximum Retention) values were calculated according to Equation 3, which varies over the years. $\mathrm{P}_{\mathrm{e}}$ effective residual precipitation values were calculated by using the $\mathrm{P}$ and $\mathrm{S}$ values found in Equation 2. Peak flow values of flood unit hydrographs were found using Equation 4 of these values. The results are given in Table 7.

Table 7. Unit hydrograph peak flow values

Hydrographs of unit hydrograph peak flows calculated according to SCS_CN Rainfall-Flow model are given in Fig.6 according to 1984, 2010, 2011 and 2019.

\subsubsection{Calculations of Peak Discharge}

In the study, hourly precipitation heights of the flood experienced on September 22, 2015 were used in order to find flood hydrographs of the basins formed by Aliyan, Gerence, Gökçeler, Çukur and Gaz streams. Pictures of the flood in the region and the hyetograph of the precipitation are given in Fig.7.

Fig.7. Flood disaster and precipitation hyetograph in the region on September 22, 2015

Flood hydrographs of basins were created by using precipitation-time values in precipitation hyetography and unit hydrograph peak flow values of 1984, 2010, 2011 and 2019 (Fig.8).

Fig.8. Flood hydrographs according to SCS-CN method

When flood hydrographs are examined, according to the land uses of 1984, 2010, 2011 and 2019, it is observed that ;

* Aliyan stream produces flood flows of $102.017 \mathrm{~m}^{3} / \mathrm{s}, 109.097 \mathrm{~m}^{3} / \mathrm{s}, 109.674 \mathrm{~m}^{3} / \mathrm{s}$ and $109.920 \mathrm{~m}^{3} / \mathrm{s}$, respectively. 
* Gerence stream produces flood flows of $158.368 \mathrm{~m}^{3} / \mathrm{s}, 165.745 \mathrm{~m}^{3} / \mathrm{s}, 166.226 \mathrm{~m}^{3} / \mathrm{s}$ and $168.534 \mathrm{~m}^{3} / \mathrm{s}$, respectively.

* Gokceler stream produces flood flows of $25.915 \mathrm{~m}^{3} / \mathrm{s}, 26.667 \mathrm{~m}^{3} / \mathrm{s}, 26.722 \mathrm{~m}^{3} / \mathrm{s}$ and $27.142 \mathrm{~m}^{3} / \mathrm{s}$, respectively.

* Cukur stream produces flood flows of $84.908 \mathrm{~m}^{3} / \mathrm{s}, 87.377 \mathrm{~m}^{3} / \mathrm{s}, 87.873 \mathrm{~m}^{3} / \mathrm{s}$ and $88.452 \mathrm{~m}^{3} / \mathrm{s}$, respectively.

* The Gas stream produces flood flows of $91.607 \mathrm{~m}^{3} / \mathrm{s}, 93.214 \mathrm{~m}^{3} / \mathrm{s}, 93.981 \mathrm{~m}^{3} / \mathrm{s}$ and $95.049 \mathrm{~m}^{3} / \mathrm{s}$, respectively.

\subsection{Multi-Criteria Decision Analysis Results}

In addition to calculating the maximum flows of streams in flood risk management, it is also very important to create visual flood risk maps of the region. In order to create flood risk maps, the most used multi-criteria decision-making analysis was used in AHP method. The first step in the establishment of the model in multi-criteria decision-making analysis is to determine the factors that affect flood. In this study, weights were determined by using parameters such as precipitation, height, slope, land use, distance to riverbed. In the study, the method was applied for 5 different basins. Since the class ranges of the parameters of each basin used in the method will be different, the weight values are determined according to the degree of importance of the class ranges they receive. In Table 8 , the weight values and class ranges of the model established in the example of Aliyan stream are given.

Table 8. Weight values assigned to the factors used in the method (Aliyan stream)

After the model established for Aliyan stream in Table 8 was created for the other 4 basins, Unclassified flood risk maps of the basins were created by analyzing Weighted Overlay in the software ArcGIS 10.2.

\subsubsection{Flood Risk Mapping}

The maps formed as a result of the analysis are in the ranges ranging from 1 to 9 in raster format. Reclassification based on the degree of importance has been made in order to make the resulting maps more understandable. The table of reclassification according to color codes is given below (Table 9).

Table 9. Reclassification criteria of flood risk maps

The flood risk maps that were made meaningful as a result of the reclassification, were created separately according to the land use change of 1984, 2010 and 2011 and are given in Fig.9.

Fig.9. Flood risk maps varying by years

In order to better understand the change in flood risk maps given in Fig.9, the risk change of the basins by years is shown with the following graphs (Fig.10).

Fig.10. Graphical representation of flood risk change in basins by years

When the change of flood risk areas is analyzed according to the years examined, a very high-risk class was not obtained for the Aliyan stream basin in 1984, while determining flood risk areas of $0.162 \mathrm{~km}^{2}$ as very low, $0.4608 \mathrm{~km}^{2}$ as low, $1.8252 \mathrm{~km}^{2}$ as medium, and $0.3033 \mathrm{~km}^{2}$ as high. However, when we look at the years 2010, 2011 and 2019, very high flood risk areas occurred at an average of 1.036\%. There was a decrease in low flood risk classes. Gerence, Gokceler, Cukur and Gaz have demonstrated that the regions where there are no low flood risk areas in any of the years studied, are already sensitive to flood risk. Therefore, it was thought that it would be correct to examine the changes in the high flood category. According to the basin area in Gerence stream basin, in high flood category, an increase of $21.2252 \%, 23.0371 \%$ and $33.6497 \%$ was observed in 2010, 2011 and 2019, respectively. Compared to 1984, Gokceler stream basin increased by $17.9507 \%, 18.5266 \%$ and $24.0433 \%$ respectively. While these risk figures were seen to increase by $18.8256 \%$, $22.5741 \%$ and $26.6088 \%$ in Cukur stream basin, it was seen as $12.2330 \%, 15.9510 \%$ and $19.3482 \%$ in Gaz stream basin. In summary, flood risks have increased in all basins with the progress of years. In the years 
studied from 1984 to 2019, the greatest increases in flood risk occurred in Aliyan, Gerence, Cukur, Gokceler and Gaz basins, respectively.

\subsection{Changes in Land Usage and Urbanization}

Many recent studies have used visual interpretation of high-resolution images to produce low-cost and reasonably accurate reference data to both produce black cover maps and test their accuracy (Clark and Aide, 2011). The images obtained from the satellite images were classified under controlled classification and the study area was evaluated under 3 categories of main land usage (Forest, Bare Land, Residential). The change of land use between 1984, 2010, 2011 and 2019 indicates that urbanization in the region has increased rapidly. With the increase of urbanization, the areas where the falling precipitation will pass directly to the flow without seeping have increased. This situation may explain the flood events that have increased in recent years. Land use maps of the basins examined in the study in 1984, 2010, 2011 and 2019 are given in Fig.11.

Fig.11. Change of land use status by years

When examined in Fig.11, the first noticeable event is the increase in residential areas shown in red from 1984 to 2019. In fact, except for the Gerence stream basin, it is observed that the forest areas shown in green are also increasing. However, it is clearly seen that the bare lands, which are shown in yellow, are replaced by forest and residential areas. The important thing here is to determine how many percent forest area and how many percent residential areas have replaced the bare land. When the data are analyzed, on average, $18.79 \%$ of the bare land areas in all basins have been replaced by forest area and $81.21 \%$ by the settlement area. This situation shows that although afforestation works are in place, settlements tend to increase at a much higher rate. This situation clearly shows that the settlement areas in the basins examined have increased rapidly and that they are under the risk of urbanization in the forested areas in the coming years.

\subsection{Relationships with Flood Discharge, Urbanization and Flood Risk}

In previous sections, the size of floods, the change in land use and the risk of floods were handled and evaluated separately. In this section, the relationship of these three parameters will be revealed. In Fig.12, the relationships between urbanization and flood risks are shown for Aliyan, Gerence, Gokceler, Cukur and Gaz Basins. When the graphics are analyzed in detail, it is clearly seen that the settlements in all basins were limited in 1984, while the settlements increased in the following years. In the same proportion, it is seen in the plots where the curve that appears with red line, increases in areas with high flood risk. Flood sizes found by the SCS-CN method also increase over the years. It is clear that the correct ratio between these three criteria comes from the urbanization factor. Due to the increase in impermeable areas due to urbanization, it was evaluated that the falling precipitation was largely flowing directly, and this situation led to increased flood flows. If we evaluate each basin in terms of urbanization and the size of the flood, then;While there was a settlement area of $0.1746 \mathrm{~km}^{2}$ in 1984 in the Aliyan basin, this area increased to $1.7172 \mathrm{~km}^{2}$ with an increase of 9.835 times in 2010. According to the SCS-CN method, the effect of this growth in the residential area on the flood size is reflected as an increase of $6.94 \%$. The flood size, which was $102.017 \mathrm{~m}^{3} / \mathrm{s}$ in 1984 , was calculated as $109.097 \mathrm{~m}^{3} / \mathrm{s}$ in 2010 . In 2011 and 2019 , residential areas continued to grow and were calculated as $1.8459 \mathrm{~km}^{2}$ and $1.9710 \mathrm{~km}^{2}$. While the flood size in 2011 was calculated as $109.674 \mathrm{~m}^{3} / \mathrm{s}$, it was found to be $109.920 \mathrm{~m}^{3} / \mathrm{s}$ in 2019. Urbanization in the Aliyan basin has grown 11.289 times from 1984 to 2019. The size of the flood of the Aliyan stream from 1984 to 2019 increased by $7.747 \%$. In the Gerence basin, while there was a settlement area of $0.3582 \mathrm{~km}^{2}$ in 1984, this area increased to 0.8055 $\mathrm{km}^{2}$ with an increase of 2.249 times in 2010. According to the SCS-CN method, the effect of this growth in the residential area on the flood size is reflected as an increase of $4.68 \%$. The flood size, which was 158.368 $\mathrm{m}^{3} / \mathrm{s}$ in 1984 , was calculated as $165.745 \mathrm{~m}^{3} / \mathrm{s}$ in 2010 . In 2011 and 2019 , residential areas continued to grow and were calculated as $0.8352 \mathrm{~km}^{2}$ and $0.9729 \mathrm{~km}^{2}$. While the flood size in 2011 was calculated as 166.226 $\mathrm{m}^{3} / \mathrm{s}$, it was found as $168.534 \mathrm{~m}^{3} / \mathrm{s}$ in 2019 . Urbanization in the Gerence basin has grown 2.716 times from 1984 to 2019. The size of floods of Gerence creek increased by $6.419 \%$ from 1984 to 2019. In the Gokceler 
basin, while there was a settlement area of $0.2727 \mathrm{~km}^{2}$ in 1984 , this area increased to $1.4418 \mathrm{~km}^{2}$ with an increase of 5.287 times in 2010. According to the SCS-CN method, the effect of this growth in the residential area on the flood size is reflected as an increase of $2.90 \%$. The flood size, which was $25.915 \mathrm{~m}^{3} / \mathrm{s}$ in 1984 , was calculated as $26.667 \mathrm{~m}^{3} / \mathrm{s}$ in 2010 . In 2011 and 2019 , residential areas continued to grow and were calculated as $1.4733 \mathrm{~km}^{2}$ and $2.1852 \mathrm{~km}^{2}$. While the size of the flood in 2011 was calculated as $26.722 \mathrm{~m}^{3} / \mathrm{s}$, it was found to be $27.142 \mathrm{~m}^{3} / \mathrm{s}$ in 2019. Urbanization in Gokceler basin has grown 8.013 times from 1984 to 2019 . The size of the flood of the Gokceler stream increased $4.735 \%$ from 1984 to 2019. While the Cukur basin had a residential area of $0.4518 \mathrm{~km}^{2}$ in 1984, this area increased to $3.1293 \mathrm{~km}^{2}$ in 2010 with an increase of 6.926 times. According to the SCS-CN method, the effect of this growth in the residential area on the flood size is reflected as an increase of $2.91 \%$. The flood size, which was $84.908 \mathrm{~m}^{3} / \mathrm{s}$ in 1984 , was calculated as $87.377 \mathrm{~m}^{3} / \mathrm{s}$ in 2010. In 2011 and 2019, residential areas continued to grow and were calculated as 3.5154 $\mathrm{km}^{2}$ and $4.4577 \mathrm{~km}^{2}$. While the flood rate in 2011 was calculated as $87.873 \mathrm{~m}^{3} / \mathrm{s}$, it was found as 88.452 $\mathrm{m}^{3} / \mathrm{s}$ in 2019. Urbanization in the Cukur basin has grown 9.867 times from 1984 to 2019. The flood size of Cukur stream increased by $4.174 \%$ from 1984 to 2019. In the Gaz basin, while there was a settlement area of $0.5778 \mathrm{~km}^{2}$ in 1984 , this area increased to $2.826 \mathrm{~km}^{2}$ with an increase of 4.891 times in 2010 . According to the SCS-CN method, the effect of this growth in the residential area on the flood size is reflected as an increase of $1.75 \%$. The flood size, which was $91.607 \mathrm{~m}^{3} / \mathrm{s}$ in 1984 , was calculated as $93.214 \mathrm{~m}^{3} / \mathrm{s}$ in 2010 . In 2011 and 2019, residential areas continued to grow and were calculated as $3.600 \mathrm{~km}^{2}$ and $5.2245 \mathrm{~km}^{2}$. While the flood size in 2011 was calculated as $93.981 \mathrm{~m}^{3} / \mathrm{s}$, it was found as $95.049 \mathrm{~m}^{3} / \mathrm{s}$ in 2019 . Urbanization in the gas basin has grown 9.042 times from 1984 to 2019. The size of the flood of the Gaz Stream from 1984 to 2019 increased by $3.757 \%$.

Fig.12. Relationships between Urbanization and Flood Risk according to the years studied

When all these data are evaluated, the highest growth in terms of urbanization was observed in the Aliyan stream basin with an increase of 11.289 times between 1984-2019. Following the Aliyan basin, Cukur, Gaz, Gokceler and Gerence basins also show an increase in urbanization respectively. As an increase in flood sizes, it was observed in the Aliyan basin again with an increase of 7.747\% between 1984-2019. Then comes Gerence, Gokceler, Cukur and Gaz basins respectively. When the changes in the flood risk areas seen with the red line in Fig.12 were examined, it was observed that the areas with high flood risk in the Aliyan basin grew 6.145 times between 1981-2019, while in the Gerence basin it increased 1.625 times, in the Gokceler basin 3.961 times, 5.238 times in the Cukur basin and 3.139 times in the Gas basin. When all these results are evaluated together collectively, Aliyan stream has attracted attention as the stream where the risk of flooding has grown the most within the five basins examined. Following the Aliyan stream, Cukur and Gokceler basins come as risky basins.

\subsection{Condition of Stream Beds in the Area}

Gokceler stream, is the first stream that is forming flood located at the entrance of the city, and it is the stream with the highest flood effect in Bodrum, although the rainfall to the basin is small. Gerence stream is the second stream of the city that runs from east to west, it is partially open section, partially closed section and it is downstream from the sea. Aliyan Stream, the third stream from east to west, Aliyan Stream is downstream from the Gumbet Beach. Cukur stream is downstream from the sea on Bitez Beach and takes the fourth place in the layout plan. Gaz stream is the fifth stream that is downstream from the sea on Bitez beach and shown from east to west in the layout plan. There are dense residential areas around each of the streams in the city center of Bodrum (Fig.13). Since some parts of the streams are covered and the road, car park, pavement and building are occupied, the drainage infrastructure is insufficient for the discharge of surface rainwater. For this reason, especially in the heavy rains, the city center is under constant flood risk. The causes of floods occurring in the city center are that the downstream of the streams are located in the city, also that there are no stream beds in the section that can transmit peak flood flows as well as unplanned urban growth. In his study, Koc et al. (2010) states that the narrowing of the stream beds as a result of improper zoning applications and land uses, the inclusion of smaller sectional channels according to the current situation, and the reduction of the cross-sectional areas for other purposes, increases the effect 
of flood events.

Fig.13 . Streams studied in Bodrum Urban Center

\section{Conclusion and Recommendations}

This study aims to establish the relationship between areas subject to flooding by urban growth, as well as climate change and flood management for Bodrum city, which is an important tourism center of Turkey. In the study, urban growth maps that show the change of urban areas for 1984, 2010, 2011 and 2019 was obtained, precipitation analyzes were performed to understand the trend of precipitation on working areas and maps of areas that might be exposed to flood hazard were produced. Floods occurring in Bodrum city center originate from Gokceler, Gerence, Aliyan, Cukur and Gaz streams. Among the five basins studied, the basin with the highest flood risk is the Aliyan stream, where urban growth is greatest. Other risky basins are basins of Cukur and Gokceler streams. The streams are located in the city center and there are dense settlements around each stream. The causes of floods occurring in the city center are that the downstream of the streams are located in the city, also that there are no stream beds in the section that can transmit peak flood flows as well as unplanned urban growth. Since the city is covered with concrete surfaces throughout the city center, the precipitation waters immediately pass to the surface flow and cause sudden floods. In addition, the drainage infrastructure is insufficient for the discharge of superficial rainwater, since all the riverbeds in the city center are occupied by building up streets, roads, parking lots, pavements and buildings. Therefore, especially in the heavy rains, the city center is under constant flood risk. The improvement of these streams will be very difficult at the application stage and will take a long time.

The fact that there is a significant increase in urban growth in the years studied causes the areas that may be affected by floods to increase. The magnitude of urban development and the direction of growth will cause the risk of flooding to increase or decrease. Variations in precipitation tendency are not the only factors that reduce or increase areas that may be affected by flood in urban areas. There is no clear relationship between precipitation and flood-protected areas in the five basins studied. However, flood-prone areas are significantly affected by the difference in the density and frequency of precipitation and the extent of urban growth. Local and national level land makers should produce permanent solutions as urban growth and growth tend to flood-prone areas, which will increase areas sensitive to flood risk. A new road to be built in the urban area or other infrastructure services away from areas with flood hazards will help avoid risky areas for both planned and unplanned urban growth. This can be an important step in reducing risk, especially for those living in areas with sudden flood risk. In addition, an integrated urban planning approach should be taken to increase the quality of life of the population and reduce the impact of floods by establishing a more concrete relationship between natural and built environments. Planners, engineers, local administrators and politicians can use maps showing areas of flood hazard for the selection of areas suitable for urban growth. Urban flood hazard maps reveal the relationship between flood hazard zones and spatial distribution of floods. Flood hazard maps should be taken into account by the authorities for the identification of areas where rainwater flow infrastructure is needed and for policies and strategies for sustainable urban development. Koc and Bozkurt (2013) necessitates the establishment of a more widespread observation network and early warning system in the basin for the accurate precipitation-flow forecast and timely early warnings to prevent loss of life and property.

\section{References}

Ahmad, T.; Pandey, A.C.; Kumar, A (2019). Evaluating urban growth and its implication on flood hazard and vulnerability in srinagar city, kashmir valley, using geoinformatics. Arab. J. Geosci. 12, 308.

Aisya Azizah Abas and Mazlan Hashim 2014 IOP Conf. Ser.: Earth Environ. Sci. 18012040. doi:10.1088/1755-1315/18/1/012040

Ajmal, M., Moon, G., Ahn, J., Kim, T. (2015). Investigation of SCS-CN and its inspired modified models for runoff estimation in South Korean watersheds. Journal of Hydro-Environment Research, 9(4), 592-603, https://doi.org/10.1016/j.jher.2014.11.003 
Amutha, R., Porchelvan, P. (2009). Estimation of surface runoff in Malattar sub-watershed using SCS-CN method. J Indian Soc Remote Sens 37, 291 https://doi.org/10.1007/s12524-009-0017-7

Barthrellos, G.D., Karymbalis, E., Skilodimou, H.D., Papanastassiou, K.G., Baltas, E.A. Urban flood hazard assessment in the basin of Athens Metropolitan city, Greece. Environ Earth Sci (2016) 75:319. Doi: $10.1007 / \mathrm{s} 12665-015-5157-1$

Brito, M.M., Evers, M. Multi-criteria decision-making for flood risk management: a survey of the current state of the art. Nat. Hazards Earth Syst. Sci., 16, 1019-1033, 2016. doi:10.5194/nhess-16-1019-2016

Buurman, J.; Babovic, V. Adaptation pathways and real options analysis: An approach to deep uncertainty in climate change adaptation policies. Policy Soc. 2016, 35, 137-150. http://dx.doi.org/10.1016/j.polsoc.2016.05.002

Chen, S.Y.; Xue, Z.C.; Li, M.; Zhu, X.P. Variable sets method for urban flood vulnerability assessment. Sci. China Technol. Sc. 2013, 56, 3129-3136. http://dx.doi.org/10.1007/s11431-013-5393-0

Chikwue, M.I. 2019. Computation of peak Flow discharge using global Mapper 15.0 to design open channel. Conference Book of proceedings. The Dynamics of Environmental Change: Impact of Engineering.

Devi, N.N.; Sridharan, B.; Kuiry, S.N (2019). Impact of urban sprawl on future flooding in chennai city, india. J.Hydrol. 574, 486-496

Google Earth, 2020, Satellite Image Landsat, Accessed time 16.03.2020.

$\mathrm{Gu}, \mathrm{D}$. Exposure and vulnerability to natural disasters for world's cities. United Nations: Department of Economic and Social Affairs. Population Division. Technical Paper, December, 2019.

Hallegatte, S.; Green, C.; Nicholls, R.J.; Corfee-Morlot, J. Future flood losses in major coastal cities. Nat. Clim. Chang. 2013, 3, 802-806. http://dx.doi.org/10.1038/nclimate1979

Hansen, R.; Pauleit, S. From multifunctionality to multiple ecosystem services? A conceptual framework for multifunctionality in green infrastructure planning for urban areas. Ambio 2014, 43, 516-529. http://dx.doi.org/10.1007/s13280-014-0510-2

Hassan, S.S., Ajmal, M., Khan, A.A., Goheer, M.A., Khattak, M.S., Ali, S., Ijaz, M., Adnan, M. (2019). Multi-criteria decision analysis for flood risk on the Chenab River. Weather. 74(1). https://doi.org/10.1002/wea.3490

Hirabayashi, Y.; Mahendran, R.; Koirala, S.; Konoshima, L.; Yamazaki, D.;Watanabe, S.; Kim, H.; Kanae, S. Global flood risk under climate change. Nat. Clim. Chang. 2013, 3, 816-821. http://dx.doi.org/10.1038/nclimate1911

Jacobson, C.R. Identification and quantification of the hydrological impacts of imperviousness in urban catchments: A review. J. Environ. Manag. 2011, 92, 1438-1448. http://dx.doi.org/10.1016/j.jenvman.2011.01.018

Jha, Abhas K., Robin Bloch, and Jesssica Lamond (2012). Cities and Flooding: A Guide to Integrated Urban Flood Risk Management for the 21st Century. Washington, DC: World Bank and Global Facility for Disaster Reduction and Recovery.

Koc, C., Bakış, R., Bayazıt, Y (2017). A study on assessing the domestic water resources, demands and its quality in holiday region of Bodrum Peninsula, Turkey". Tourism Management, Volume 62, 10-19

Koç, C., Bozkurt, H (2013). Büyük Menderes Havzasında Taşkınların Entegre Havza Yönetimiyle Kontrol Edilmesi Üzerine bir Çalı̧̧ma [A Study on the Control of Floods in Büyük Menderes Basin by Integrated Watershed Management]". 3. Ulusal Taşkın Sempozyumu, 29-30 Nisan 2013, Tebliğler kitabı, 95-102s. Haliç Kongre Merkezi. İstanbul. 
Koç, C., Kosif, K., Kızıltepe, S., Özdemir, K (2010). Büyük Menderes ve Batı Akdeniz Havzalarında İşletmede olan Taşkın Tesislerine Yapılan Müdahaleler Üzerine Bir Çalışma [A Study on Intervations on Flood Facilities Operated in Büyük Menderes and West Mediterranean Basins] ". II. Ulusal Taşkın Sempozyumu 22-24 Mart, Afyonkarahisar, 71-79.

Kousari, M.R., Malekinezhad, H., Ahani, H., Zarch, M.A.A. 2010. Sensitivity analysis and impact quantification of the main factors affecting peak discharge in the SCS curve number method: An analysis of Iranian watersheds. Quaternary International. 226(1-2): 66-74. https://doi.org/10.1016/j.quaint.2010.05.011

Kuang, W.H.; Chen, L.J.; Liu, J.Y.; Xiang, W.N.; Chi, W.F.; Lu, D.S.; Yang, T.R.; Pan, T.; Liu, A.L. Remote sensing-based artificial surface cover classification in Asia and spatial pattern analysis. Sci. China Earth Sci. 2016, 59, 1720-1737. http://dx.doi.org/10.1007/s11430-016-5295-7

Liao, K.-H.(2012). A theory on urban resilience to floods-A basis for alternative planning practices. Ecol. Soc.17.

Liu, Y.Z.; Bralts, V.F.; Engel, B.A. Evaluating the e ectiveness of management practices on hydrology and water quality at watershed scale with a rainfall-runo model. Sci. Total Environ. 2015, 511, 298-308. https://linkinghub.elsevier.com/retrieve/pii/S0048969714017884

Lockaby, G., Nagy, C., Vose, J.M., et al., 2011. Water and forests. In: Wear, D.N., Greis, J.G. (Eds.), Southern Forest Futures Project, Chapter 13. 85 p.

Maden Tetkik ve Arama Genel Müdürlüğü (MTA), 2020. Yerbilimleri Harita Görüntüleyici ve Çizim Editörü Version 2.9, Accessed Time 15.03.2020, http://yerbilimleri.mta.gov.tr/anasayfa.aspx

Matomela, N., Tianxin, L., Morahanye, L., Bishoge, O.K., Ikhumhen, O. 2019. Rainfall-runoff estimation of Bojiang lake watershed using SCS-CN model coupled with GIS for watershed management. Journal of Applied and Advanced Research. 4(1):16-24. http://dx.doi.org/10.21839/jaar.2019.v4i1.263

Miller, J.D.; Hutchins, M. (2017). The impacts of urbanisation and climate change on urban flooding and urban water quality: A review of the evidence concerning the United Kingdom. J. Hydrol. Reg. Stud. 12, $345-362$.

Mishra, A.K. (2015). A study on the occurrence of flood events over jammu and kashmir during september 2014 using satellite remote sensing. Nat. Hazards, 78, 1463-1467.

Mishra, K., Sinha, R. Flood risk assessment in the Kosi megafan using multi-criteria decision analysis: A hydro-geomorphic approach. Geomorphology. 350(1). 2020. https://doi.org/10.1016/j.geomorph.2019.106861

O'Driscoll, M., Clinton, S., Jefferson, A., et al., 2010. Urbanization effects on watershed hydrology and in-stream processes in the Southern United States. Water 2, 605-648. https://doi.org/10.3390/w2030605.

P. Pettersson, M.; Priest, S.; Suykens, C.; et al. (2018) Governance Strategies for Improving Flood Resilience in the Face of Climate Change. Water, 10, 1595.

Paliaga, G., Faccini, F., Luino, F., Turconi, L. A spatial multicriteria prioritizing approach for geohydrological risk mitigation planning in small and densely urbanized Mediterranean basins. Nat. Hazards Earth Syst. Sci., 19, 53-69, 2019. https://doi.org/10.5194/nhess-19-53-2019

Pathirana, A.; Denekew, H.B.; Veerbeek,W.; Zevenbergen, C.; Banda, A.T. (2014). Impact of urban growthdriven landuse change on microclimate and extreme precipitation-A sensitivity study. Atmos. Res. 138, $59-72$

Salimi, E.T., Nohegar, A., Malekian, A., Hoseini, M., Holisaz, A. 2017. Estimating time of concentration in large watersheds. Paddy and Water Environment. 15(1):123-132. Doi: 10.1007/s10333-016-0534-2

Sanyal, J.; Lu, X. (2004). Application of remote sensing in flood management with special reference to monsoon asia: A review. Nat. Hazards, 33, 283-301. 
Satheeshkumar, S., Venkateswaran, S., Kannan, R. 2017. Rainfall-runoff estimation using SCS-CN and GIS approach in the Pappiredipatti watershed of the Vaniyar sub basin, South India. Model. Earth Syst. Environ. 3(24):1-8. Doi: 10.1007/s40808-017-0301-4

Scholz, M. (2004). "Case study: Design, operation, maintenance and water quality management of sustainable storm water ponds for roof runoff'l;. Bioresource Technology, 95, 269-279.

Shadeed, S., Almasri, M. Application of GIS-based SCS-CN method in West Bank catchments, Palestine. Water Science and Engineering, 3(1), 1-13, (2010). https://doi.org/10.3882/j.issn.1674-2370.2010.01.001

Sörensen, J.; Mobini, S (2017). Pluvial, urban flood mechanisms and characteristics-assessment based on insurance claims. J. Hydrol. 555, 51-67

Sudhakar BS, Anupam KS, Akshay OJ (2015) Snyder Unit Hydrograph and GIS for Estimation of Flood for Un-Gauged Catchments in Lower Tapi Basin, India. Hydrol Current Res 6: 195. doi:10.4172/21577587.1000195

TSI (2019). Turkey Population Statistics, www.tuik.gov.tr. Date of access: April 15, 2020.

Umar, N.K., Abdullahi, H.S., Usman, A.K. (2019). A Multi-Criteria Decision Support System in the Analysis Of Flood Risk and Vulnerability Mapping in Suleja, Niger State, Nigeria. Proceedings of the International Cartographic Association. https://doi.org/10.5194/ica-proc-2-137-2019

UNISDR. Economic Losses, Poverty \& Disasters -1998-2017 (2017) Centre for Research on the Epidemiology of Disasters \& UN O_ce for Disaster Risk Reduction: Genebra, Switzerland, 2017.

United Nations. 2018 Revision of World Urbanization Prospects. New York, NY, USA, 2018.

U.S. Geological Survey, 2020, Earth Explorer Web Site, accessed April 16, 2020, at URL https://earthexplorer.usgs.gov/

USDA (1972) Soil Conservation Service, National Engineering Handbook. Hydrology Section 4. Chapters 4-10. Washington, D.C: USDA

Wahl, T.; Jain, S.; Bender, J.; Meyers, S.D.; Luther, M.E. Increasing risk of compound flooding from storm surge and rainfall for major US cities. Nat. Clim. Chang. 2015, 5, 1093-1097. http://dx.doi.org/10.1038/nclimate2736

Walega, A., Amatyab, D. M., Caldwellc, P., Mariond, D., Pandae, S. Assessment of storm direct runoff and peak flow rates using improved SCS-CN models for selected forested watersheds in the Southeastern United States. Journal of Hydrology: Regional Studies 27 (2020) 100645. https://doi.org/10.1016/j.ejrh.2019.100645

Walega, A., Salata, T. Influence of land cover data sources on estimation of direct runoff according to SCS-CN and modified SME methods. Catena, 172, 232-242, (2019). https://doi.org/10.1016/j.catena.2018.08.032

Walsh, C.J., Booth, D.B., Burns, M.J., et al., 2016. Principles for urban stormwater management to protect stream ecosystems. Freshw. Sci. 35 (1). https://doi.org/10. 1086/685284.

Xiao, B., Wang, Q. H., Fan, J., Han, F. P. and Dai, Q. H. 2011. Application of the SCS-CN model to runoff estimation in a small watershed with high spatial heterogeneity. Pedosphere. 21(6): 738-749. https://doi.org/10.1016/S1002-0160(11)60177-X

Yan, H. Bin, Huynh, V. N., and Nakamori, Y.: A probabilistic model for linguistic multi-expert decision making involving semantic overlapping, Expert Syst. Appl., 38, 8901-8912, doi:10.1016/j.eswa.2011.01.105, 2011.

Yoon, K.P. and Hwang, C.L. (1995) Multiple Attribute Decision Making: An Introduction. Sage Publication, London. 
Zagonari, F. and Rossi, C.: A heterogeneous multi-criteria multiexpert decision-support system for scoring combinations of flood mitigation and recovery options, Environ. Model. Softw., 49, 152-165, doi:10.1016/j.envsoft.2013.08.004, 2013.

Zhou, Q.; Leng, G.; Su, J.; Ren, Y (2019). Comparison of urbanization and climate change impacts on urban flood volumes: Importance of urban planning and drainage adaptation. Sci. Total Environ.

Table 1. Landsat scenes used in the study

\begin{tabular}{llll}
\hline Satellite Images Type & Date $($ yyyy $/ \mathbf{m m} / \mathbf{d d})$ & Spatial Resolution $\mathbf{( m )}$ & Cloud Cover \\
\hline Google Satellite Imagine & $1984 / 12 / 31$ & 15 & $0 \%$ \\
Landsat 4-5 TM C1 Level-1 & $2010 / 10 / 10$ & 30 & $0 \%$ \\
Landsat 4-5 TM C1 Level-1 & $2011 / 10 / 13$ & 30 & $0 \%$ \\
Google Satellite Imagine & $2019 / 06 / 26$ & 15 & $0 \%$ \\
\hline
\end{tabular}

Table 2. Features of precipitation data used in the study

\begin{tabular}{llll}
\hline $\begin{array}{l}\text { Meteorology Station } \\
\text { ID }\end{array}$ & Coordinates (UTM) & Time Period (yrs) & Data Type \\
\hline 370275 & 544490.695 Easting & $1979-2014$ & Daily \\
& 4094956.116 Northing & & \\
370272 & 516683.960 Easting & $1979-2014$ & Daily \\
& 4094855.717 Northing & & Daily \\
370278 & 572297.798 Easting & $1979-2014$ & \\
& 4095147.796 Northing & & \\
\hline
\end{tabular}

Table 3. SCS hydrologic soil groups (U.S Conservation Service, 1972)

\section{HSG Type of soil}

A Deep, well drained sands and gravels

B Moderately deep, well drained with moderately fine to coarse textures

C Clay loams, shallow sandy loam, soils with moderately fine to fine textures

D Clay soils of high swelling potential, soils with a permanent high-water table, and shallow soils over nearly impervi

Table 4. The importance of weight values in Analytical Hierarchy Process

\begin{tabular}{ll}
\hline Weight Value & Severity Rating \\
\hline 1 & Equally important \\
3 & Somewhat more important (Less superiority) \\
5 & Quite important (Superiority) \\
7 & Very important (Superiority) \\
9 & Extremely important (Absolute Superiority) \\
$2,4,6,8$ & Intermediate values (Reconciliation values) \\
\hline
\end{tabular}

Table 5. Land use change and $\mathrm{CN}$ values of the basins examined in the study by years 


\begin{tabular}{|c|c|c|c|c|c|c|c|c|c|c|c|}
\hline Basin & Year & Land use & Area (\%) & $\mathrm{CN}$ & Year & Area (\%) & $\mathrm{CN}$ & Year & Area (\%) & $\mathrm{CN}$ & Year \\
\hline \multirow[t]{3}{*}{$\overline{\text { Aliyan }}$} & \multirow[t]{6}{*}{1984} & Forest & 10.973 & \multirow[t]{3}{*}{79.303} & \multirow[t]{3}{*}{2010} & 1.245 & \multirow[t]{3}{*}{84.113} & \multirow[t]{3}{*}{2011} & 0.572 & \multirow[t]{3}{*}{84.511} & \multirow[t]{15}{*}{2019} \\
\hline & & Bare Land & 82.497 & & & 34.534 & & & 30.394 & & \\
\hline & & Residential & 6.529 & & & 64.221 & & & 69.034 & & \\
\hline \multirow[t]{3}{*}{ Gerence } & & Forest & 1.597 & \multirow[t]{3}{*}{81.644} & & 0 & \multirow[t]{3}{*}{85.017} & & 0 & \multirow[t]{3}{*}{85.239} & \\
\hline & & Bare Land & 64.958 & & & 24.789 & & & 22.017 & & \\
\hline & & Residential & 33.445 & & & 75.210 & & & 77.983 & & \\
\hline \multirow[t]{3}{*}{ Gökçeler } & & Forest & 19.017 & \multirow[t]{3}{*}{79.096} & & 21.829 & \multirow[t]{3}{*}{81.084} & & 17.365 & \multirow[t]{3}{*}{81.228} & \\
\hline & & Bare Land & 75.025 & & & 46.667 & & & 50.442 & & \\
\hline & & Residential & 5.959 & & & 31.504 & & & 32.193 & & \\
\hline \multirow[t]{3}{*}{ Çukur } & & Forest & 20.418 & \multirow[t]{3}{*}{78.959} & & 28.638 & \multirow[t]{3}{*}{80.976} & & 23.983 & \multirow[t]{3}{*}{81.384} & \\
\hline & & Bare Land & 74.982 & & & 39.498 & & & 40.222 & & \\
\hline & & Residential & 4.600 & & & 31.864 & & & 35.796 & & \\
\hline \multirow[t]{3}{*}{ Gaz } & & Forest & 21.527 & \multirow[t]{3}{*}{78.940} & & 32.965 & \multirow[t]{3}{*}{80.154} & & 28.679 & \multirow[t]{3}{*}{80.736} & \\
\hline & & Bare Land & 73.839 & & & 44.375 & & & 42.455 & & \\
\hline & & Residential & 4.633 & & & 22.660 & & & 28.866 & & \\
\hline
\end{tabular}

Table 6. Basin Parameters

\begin{tabular}{lllllll}
\hline Basin & Area $\left(\mathrm{km}^{\mathbf{2}}\right)$ & $\mathbf{L}(\mathbf{m})$ & $\mathbf{H}(\mathbf{m})$ & Slope $(\mathbf{H} / \mathbf{L})$ & Tc $(\mathbf{m i n})$ & Tp $(\mathbf{m i n})$ \\
\hline Aliyan & 2.674 & 1826.163 & 36 & 0.0197135 & 29.439586 & 20.607710 \\
Gerence & 1.071 & 1486.878 & 108 & 0.0726354 & 15.210373 & 10.647261 \\
Gökçeler & 4.577 & 4951.045 & 60.4 & 0.0121995 & 76.331828 & 53.432279 \\
Çukur & 9.821 & 7354.692 & 335 & 0.0455492 & 62.340421 & 43.638295 \\
Gaz & 12.471 & 7781.465 & 321 & 0.0412519 & 67.639664 & 47.347765 \\
\hline
\end{tabular}

Table 7. Unit hydrograph peak flow values

\begin{tabular}{lllllll}
\hline Years & Basin & $\mathbf{C N}$ & $\mathbf{S}$ & $\mathbf{P}(\mathbf{m m})$ & $\mathbf{P}_{\mathbf{e}}(\mathbf{m m})$ & $\mathbf{q}_{\mathbf{p}}\left(\mathbf{m}^{\mathbf{3}} / \mathbf{s} / \mathbf{c m}\right)$ \\
\hline 1984 & Aliyan & 79.303 & 66.291 & 303.259 & 236.044 & 6.371 \\
& Gerence & 81.644 & 57.108 & 303.404 & 244.217 & 5.109 \\
& Gökçeler & 79.096 & 67.127 & 303.439 & 235.504 & 4.196 \\
& Cukur & 78.959 & 67.683 & 308.441 & 239.855 & 11.228 \\
\multirow{2}{*}{2010} & Gaz & 78.940 & 67.763 & 308.568 & 239.909 & 13.144 \\
& Aliyan & 84.113 & 47.976 & 303.259 & 252.426 & 6.813 \\
& Gerence & 85.017 & 44.765 & 303.404 & 255.594 & 5.348 \\
& Gökçeler & 81.084 & 59.256 & 303.439 & 242.341 & 4.318 \\
& Çukur & 80.976 & 59.672 & 308.441 & 246.832 & 11.555 \\
\multirow{5}{*}{2011} & Gaz & 80.154 & 62.892 & 308.568 & 244.119 & 13.374 \\
& Aliyan & 84.511 & 46.552 & 303.259 & 253.762 & 6.849 \\
& Gerence & 85.239 & 43.987 & 303.404 & 256.334 & 5.363 \\
& Gökçeler & 81.228 & 58.699 & 303.439 & 242.834 & 4.327 \\
& Çukur & 81.384 & 58.101 & 308.441 & 248.231 & 11.620 \\
& Gaz & 80.736 & 60.607 & 308.568 & 246.127 & 13.484 \\
& Aliyan & 84.681 & 45.949 & 303.259 & 254.330 & 6.864 \\
& Gerence & 86.310 & 40.287 & 303.404 & 259.895 & 5.438 \\
& Gökçeler & 82.352 & 54.433 & 303.439 & 246.659 & 4.395 \\
& Çukur & 81.862 & 56.277 & 308.441 & 249.868 & 11.697
\end{tabular}




\begin{tabular}{cllllll}
\hline Years & Basin & $\mathbf{C N}$ & $\mathbf{S}$ & $\mathbf{P}(\mathbf{m m})$ & $\mathbf{P}_{\mathbf{e}}(\mathbf{m m})$ & $\mathbf{q}_{\mathbf{p}}\left(\mathbf{m}^{\mathbf{3}} / \mathbf{s} / \mathbf{c m}\right)$ \\
\hline & Gaz & 81.550 & 57.464 & 308.568 & 248.923 & 13.637 \\
\hline
\end{tabular}

Table 8. Weight values assigned to the factors used in the method (Aliyan stream)

\begin{tabular}{|c|c|c|c|c|}
\hline Factors Affecting Flood & Influence $(\%)$ & Classes & Classes & Scale Value \\
\hline \multirow[t]{3}{*}{ Rainfall (mm) } & \multirow[t]{3}{*}{20} & $<302$ & $<302$ & 5 \\
\hline & & $302-304$ & $302-304$ & 7 \\
\hline & & $>304$ & $>304$ & 9 \\
\hline \multirow{6}{*}{ Elevation $(\mathrm{m})$} & \multirow[t]{6}{*}{10} & $<50$ & $<50$ & 9 \\
\hline & & $50-100$ & $50-100$ & 8 \\
\hline & & $100-150$ & $100-150$ & 7 \\
\hline & & $150-200$ & $150-200$ & 5 \\
\hline & & $200-250$ & $200-250$ & 3 \\
\hline & & $>250$ & $>250$ & 1 \\
\hline \multirow[t]{6}{*}{ Slope $\left(^{\circ}\right)$} & \multirow[t]{6}{*}{15} & $0-5$ & $0-5$ & 9 \\
\hline & & $5-10$ & $5-10$ & 8 \\
\hline & & $10-15$ & $10-15$ & 7 \\
\hline & & $15-20$ & $15-20$ & 5 \\
\hline & & $20-25$ & $20-25$ & 3 \\
\hline & & $>25$ & $>25$ & 1 \\
\hline \multirow[t]{3}{*}{ Landuse } & \multirow[t]{3}{*}{25} & Forest & Forest & 1 \\
\hline & & Bare Land & Bare Land & 5 \\
\hline & & Residential & Residential & 9 \\
\hline \multirow[t]{15}{*}{ Distance with Ordered Streams (m) } & \multirow[t]{5}{*}{5} & \multirow[t]{5}{*}{ First Order } & $0-20$ & 9 \\
\hline & & & $20-40$ & 8 \\
\hline & & & $40-60$ & 7 \\
\hline & & & $60-80$ & 6 \\
\hline & & & $80-100$ & 5 \\
\hline & \multirow[t]{5}{*}{10} & \multirow[t]{5}{*}{ Second Order } & $0-20$ & 9 \\
\hline & & & $20-40$ & 8 \\
\hline & & & $40-60$ & 7 \\
\hline & & & $60-80$ & 6 \\
\hline & & & $80-100$ & 5 \\
\hline & \multirow[t]{5}{*}{15} & \multirow[t]{5}{*}{ Third Order } & $0-20$ & 9 \\
\hline & & & $20-40$ & 8 \\
\hline & & & $40-60$ & 7 \\
\hline & & & $60-80$ & 6 \\
\hline & & & $80-100$ & 5 \\
\hline
\end{tabular}

Table 9. Reclassification criteria of flood risk maps

\begin{tabular}{llll}
\hline Degree of Importance & Flood Risk & Color Code & Color \\
\hline 1 & Very Low & HSV $(120,100,38)$ & Dark Green \\
2 & & & \\
3 & Low & $\operatorname{HSV}(70,100,77)$ & Light Green \\
4 & Moderate & $\operatorname{RGB}(255,255,0)$ & Yellow \\
5 & & &
\end{tabular}




\begin{tabular}{llll}
\hline Degree of Importance & Flood Risk & Color Code & Color \\
\hline 6 & High & RGB $(255,170,0)$ & Orange \\
7 & & & \\
8 & Very High & $\operatorname{HSV}(0,100,100)$ & Red \\
9 & & & \\
\hline
\end{tabular}
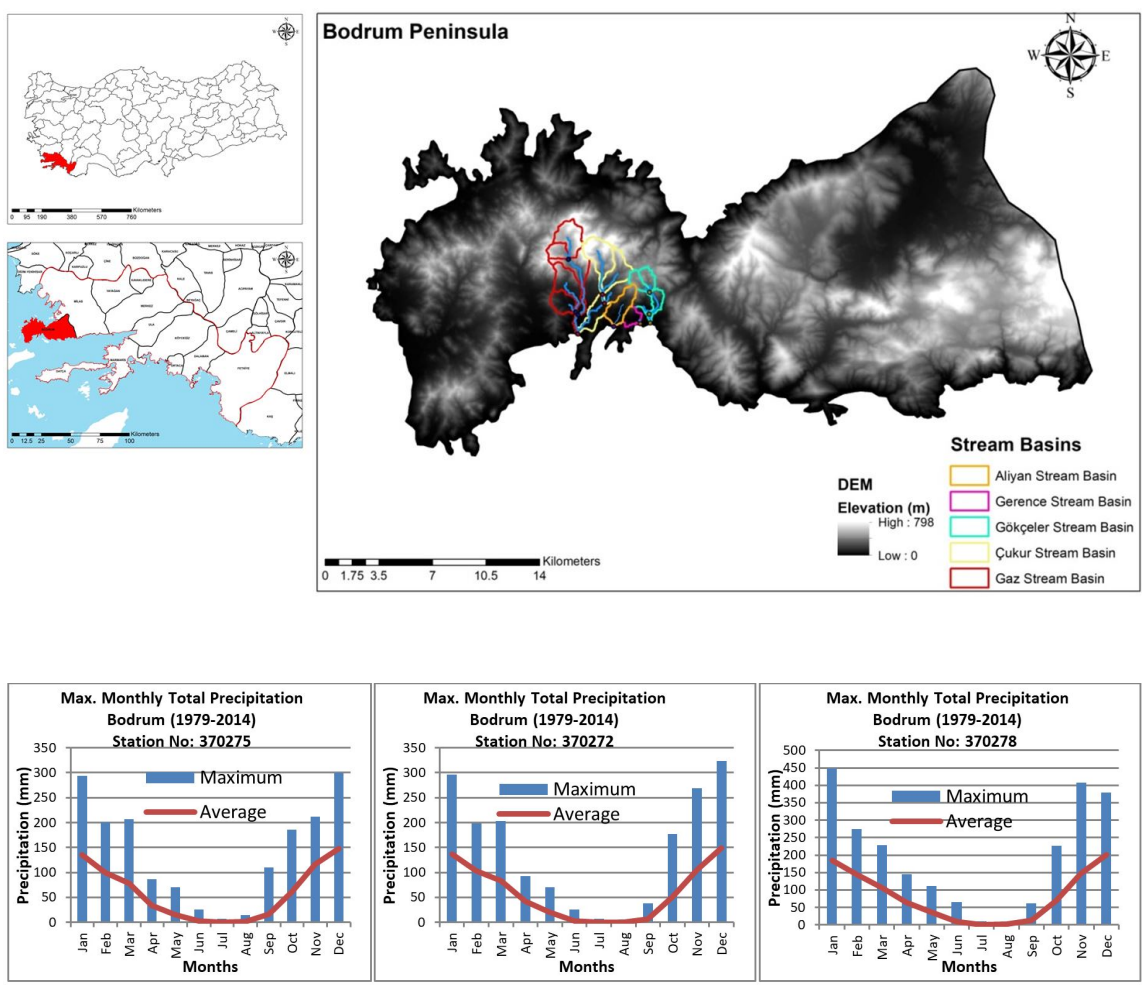

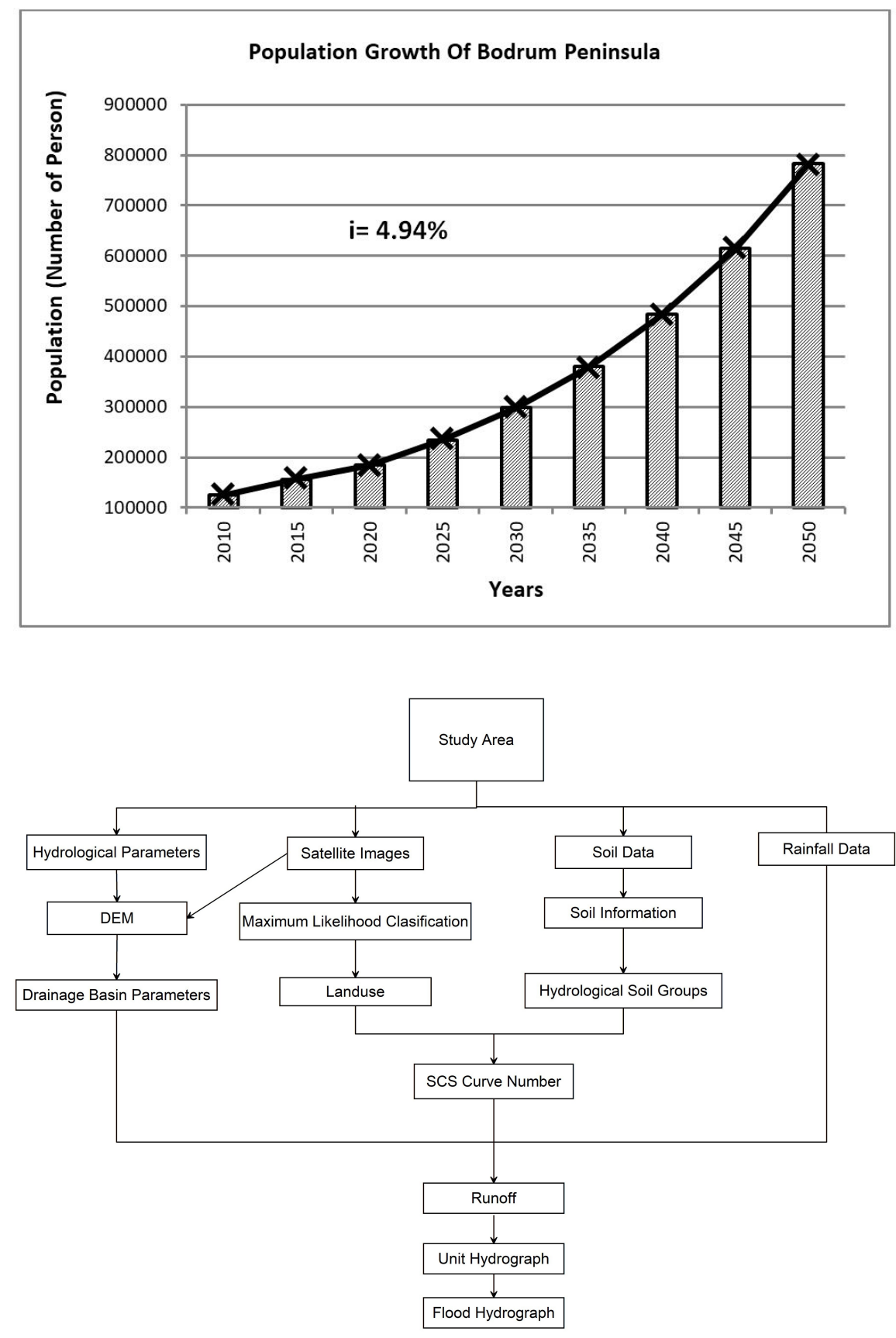

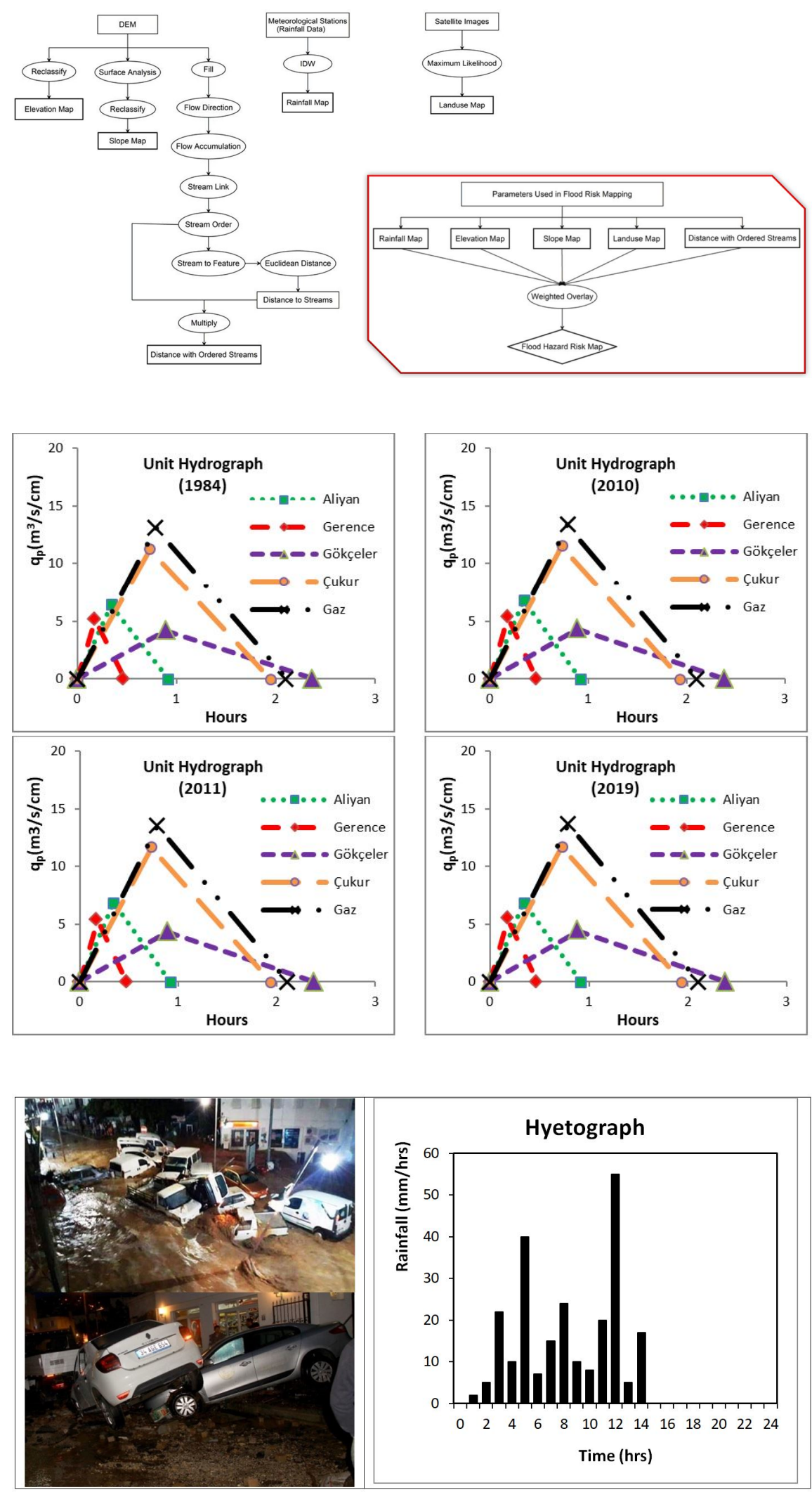

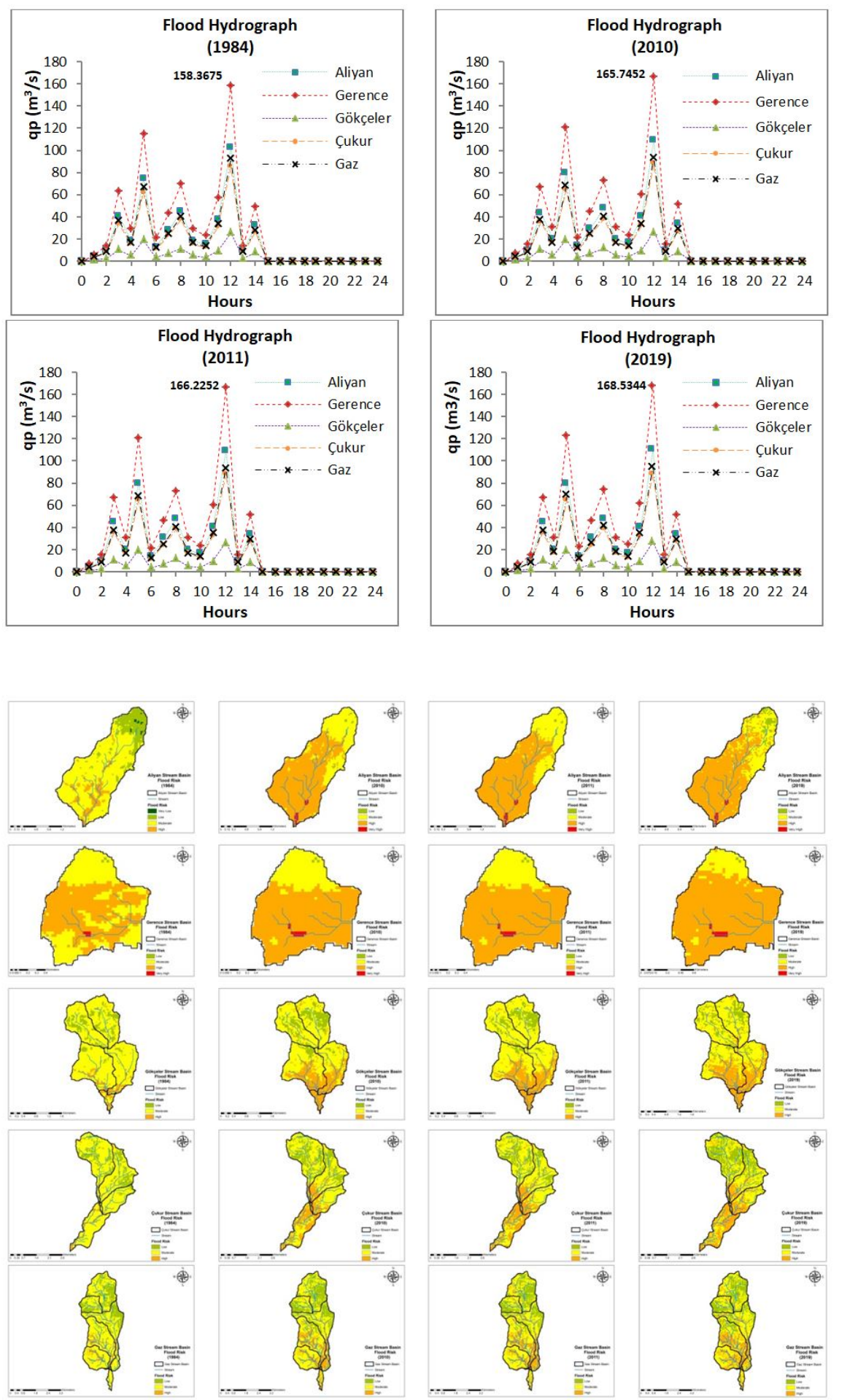

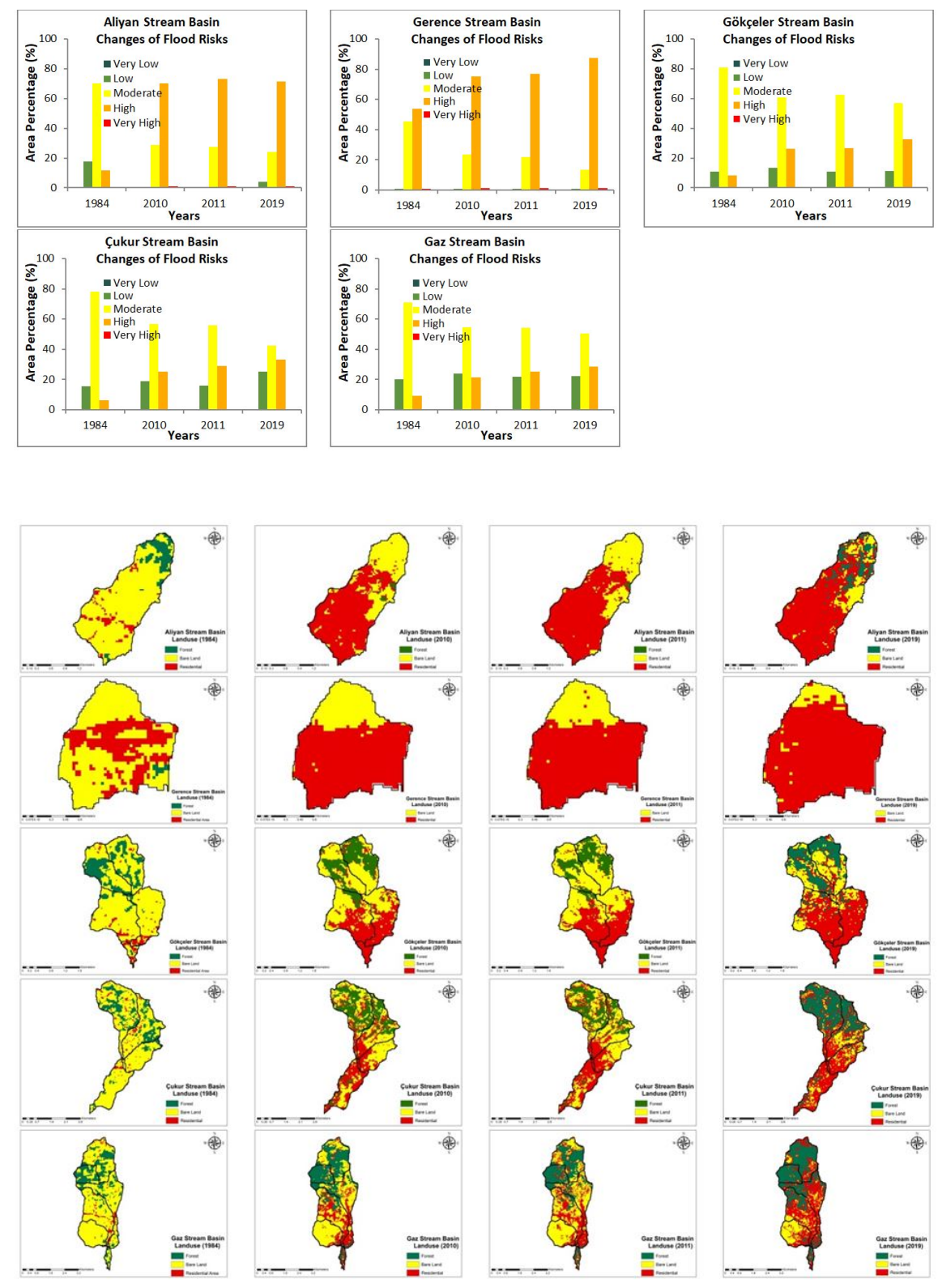

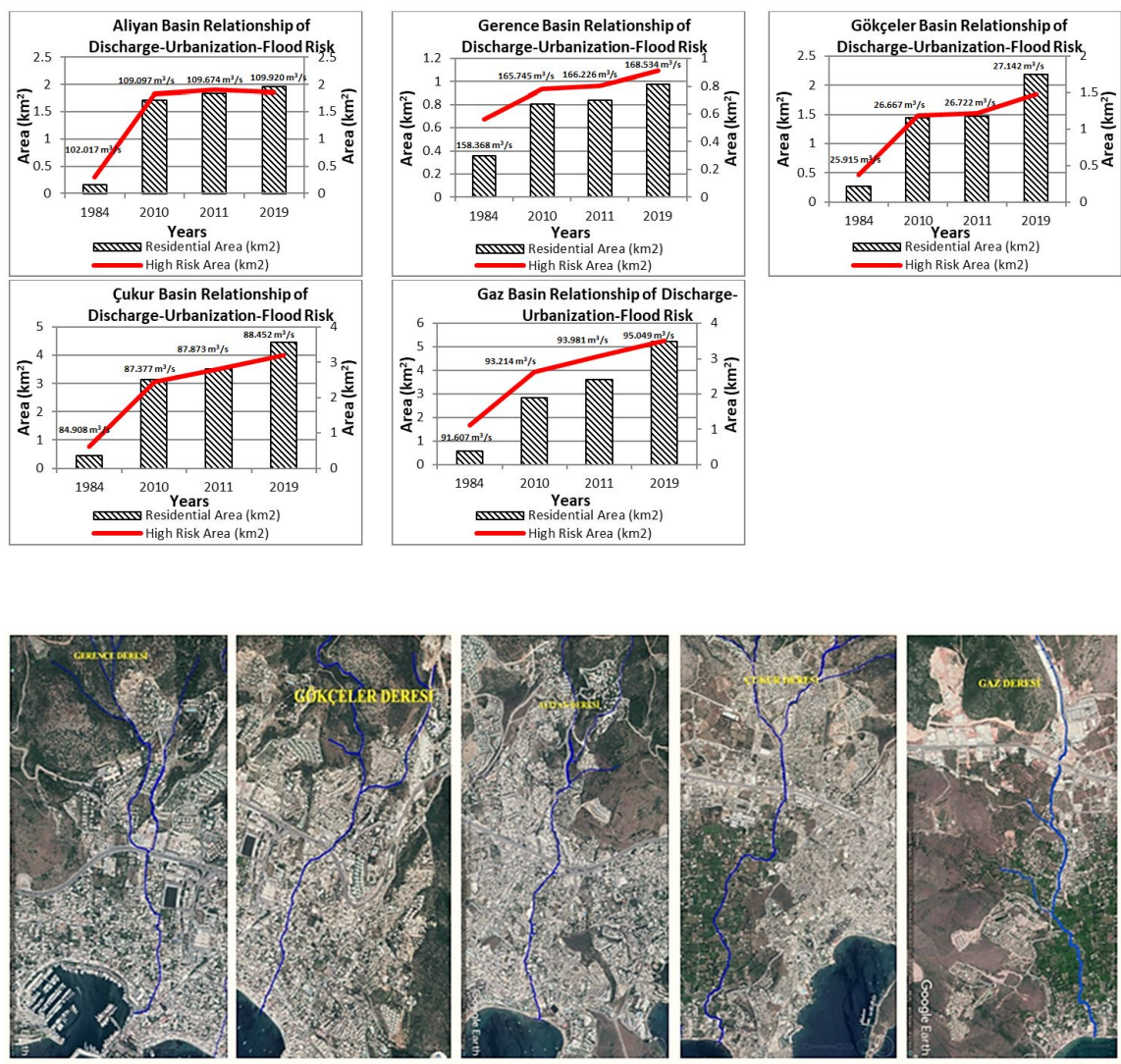

Gerence streem

Gökçeler streem

Aliyan streem

Çukur streem

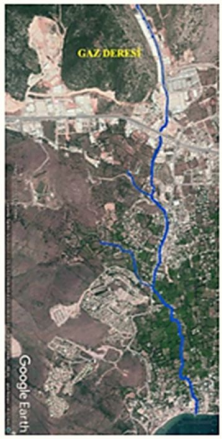

Gaz streem 